\title{
Japanese Writing Course Construction and Its Problems
}

\author{
Qing Yan \\ School of Foreign Studies, Xi`an University, Xi’an, Shaanxi, 710065
}

Keywords: Japanese Writing Course, Problems, Countermeasures

\begin{abstract}
Japanese writing ability is one of the means to test the language ability of Japanese learners. At present, the writing ability of Japanese majors is relatively weak. How to improve the teaching mode according to the current situation and how to improve students' Japanese writing ability are important tasks to be studied in the course of Japanese writing.
\end{abstract}

\section{Introduction}

With the continuous deepening of economic cooperation between China and Japan, the demand for Japanese talents with applied Japanese talents has become increasingly prominent. Applied Business Japanese Talents is different from the traditional Japanese talented people is important not only to be proficient in Japanese professional knowledge, but also to understand the Japanese way of thinking, to understand the business environment of Japanese language habits and corporate culture, with Japanese business activities ability. Of course, personnel training can not be separated from education. The purpose of education is to deliver talents that meet the needs of society. Therefore, education should be adapted to the development of society. With the changes in the needs of enterprises, the traditional Japanese education model that focuses on "grammar and vocabulary" one-sidedly is far from being able to adapt to changes in social needs. Therefore, the training of applied Japanese talents has become the major university Japanese professional consensus. According to the latest statistics, at present there are 671 Japanese majors in various institutions of higher learning in China, of which the number of Japanese majors (or directions) has reached 235, accounting for 35\% of the total number of majors in Japanese [1]. However, at present, the research on Japanese education in China has just started, and the research on the construction of specific courses is rare. Japanese writing as an output skill of the five Japanese skills of "listening, speaking, reading, writing and translating" is an important way to test the ability of using Japanese in a comprehensive manner. Japanese writing course as a vehicle to develop this skill is further The important part of improving students' language ability and professional ability plays an important role in realizing the goal of professional personnel training. However, through analyzing the present situation of traditional Japanese writing teaching, it is found that there are mainly following problems: the content of teaching is separated from the needs of enterprises, the teaching methods and assessment methods are single, and the practice teaching is not enough. Which restricts the improvement of the teaching effectiveness of the course and makes it hard to realize the supporting role of the target of "Applied Japanese Talents". Therefore, this article will take "Japanese writing course" as the research object, based on the characteristics of Japanese teaching, based on the investigation and analysis of the needs of enterprises, to explore the teaching mode of this course and to put forward personal and superficial views, with a view to Japanese Teaching reform contribute a meager amount.

\section{Japanese writing characteristics and ability requirements}

At present, there is no unified conclusion about the understanding of Japanese and Japanese ability in academia. However, the basic consensus formed is that Japanese is different from Japanese in general according to the ESP theory and should fall into the category of Japanese for special purposes. And has the following characteristics: (1) Learner-centered language education; (2) More emphasis on application than research; (3) More emphasis on practice than theory; (4) 
More emphasis on language use than linguistic structure; (5) Compared with linguistic competence Pay more attention to the language application ability; (6) compared with purely language ability to pay more attention to the comprehensive practical ability; (7) compared with the pursuit of the correctness of language, pay more attention to the actual effect of language; (8) business knowledge, business practices, social and cultural knowledge Indispensable important content.

Business writing is based on economic life as the object of reflection, language and language as a means of expression, articles as a carrier of information dissemination to promote economic development should be its goal of social practice. It is the edge of writing, information science, linguistics, logic and economics and other disciplines formed by the cross. Business writing requires basic business knowledge, and its articles have their own distinctiveness, professionalism, and normativity both in content and form.

According to the requirements of Japanese proficiency and the features of business writing, the requirements for writing ability in Japanese can be summarized as follows: "In the business scene involving Japan, using Japanese as a language tool, following Japanese business writing format and Japanese business etiquette requirements, applying appropriate professional vocabulary as well as the ability of style writing business paperwork. "

\section{Japanese writing course teaching mode exploration}

Teaching content is interactive with teachers and students in the process of teaching, serving the purpose of teaching to achieve dynamically generated material and information, so the teaching content to be determined and arrangements should be carried out around the teaching objectives. Traditional Japanese writing courses mostly focus on cultivating students' Japanese writing skills and writing literacy. Therefore, the contents of the course mainly focus on daily writing exercises such as "My One Day" and "My College Life". Japanese writing course, as a part of applied Japanese professional training system, should play a supporting and supporting role in achieving the goal of professional training. Therefore, we should not only cultivate basic Japanese writing skills, but also deepen students' understanding of business processes and work contents so as to foster their ability to comprehensively use the knowledge they have learned and analyzed to solve problems in business situations. In the meantime, they can further improve the information processing and Self-learning ability, thereby enhancing the professionalism and employability of students. In order to achieve the above-mentioned curriculum development goals, we should consider the following aspects in selecting the course contents:

The purpose of Japanese teaching is to cultivate applied Japanese talents that meet the needs of the enterprise and adapt to the work environment and job requirements in a relatively short period of time. Therefore, when determining the teaching content, we should first conduct research on the needs of the enterprises so that they can be targeted. Taking our school as an example, after conducting a survey on a number of enterprises involved in the field in the Dalian Software Park, we made clear that during the actual work process, e-mails, minutes, messages, reports, proposals, quotations, Business writing instruments such as invitations are frequently used, and companies are also expecting graduates to master the writing norms and points of these instruments. Therefore, we use the above business documents as the main content of the course. In addition, with the popularity of the Internet, e-mail has become the main way for companies to communicate internally or externally with the need for intensive intensive training in the e-mail format. Therefore, according to the purpose of writing, the e-mail part is divided into invitations, please, thanks, apologies, questions, notices and other modules, as far as possible, covering daily social and social e-mail categories.

For students, near the end of graduation will face job search, study abroad, how to write resumes and study abroad volunteer is also a practical problem students, therefore, considering the needs of students, we also joined the part of the content, through the help Students solve practical problems to change students' understanding of writing lessons and improve their learning interest and enthusiasm. 
Writing ability is a gradual process of training, if you do not have the basic knowledge of writing began to business writing training, students will inevitably produce fear, or even psychological exclusion. Therefore, from the perspective of foreign language learning, it is necessary to add some basic knowledge of writing, such as the use of manuscripts and punctuation marks, simplified and honored subjects, and common analysis of misuse and expression, laying a good foundation for students' actual writing in the future. Of course, the above content is based on the broad concept of Japanese teaching and does not specifically refer to the "trade", "clothing" and other professional fields, in the actual teaching process, according to the professional training objectives of specific personnel, to increase the content of the course Less.

The project pedagogy is a learning method based on constructivist learning theory and socio-cultural theory. It transforms the knowledge contents of traditional disciplinary system into several teaching projects, and focuses on the teaching of project organization, which enables students to directly participate in the whole teaching process of the project. The most prominent feature of the project pedagogy is that it takes the project as the main line, the teacher as the guide, and the students as the main body, which has changed the passive teaching mode of "teacher speaking and student listening" in the past and created the students' initiative participation, independent collaboration and exploration and innovation The new teaching model is a typical student-centered approach to teaching.

Cooperative pedagogy mainly uses the division of labor and resources sharing among the group members to learn, and makes use of the group-based evaluation and assessment and the competition among the groups to create a social psychology atmosphere of "catch-up" so as to enhance the learning effect. Cooperative pedagogy puts teaching emphasis on "learning" of students, pays more attention to the dominant position of students, and pays attention to meeting students' psychological needs. However, teachers mainly play a guiding role. In addition, throughout the teaching process, each student is able to participate in it. The enthusiasm of students is greatly improved. In the process of mutual cooperation, students' awareness and ability of team cooperation have also been developed and improved.

In the actual process of teaching, due to the learning objects we face, the characteristics of the teaching content in each chapter and the emphasis of teaching are all different. Therefore, it is necessary to select and comprehensively use various teaching methods. The following will be my school Japanese writing teaching as an example, the implementation of the curriculum project-oriented, specific introduction to the practical application of various practical teaching methods.

Based on the practicality of the Japanese writing course, this project has been designed to simulate a corporate trade fair and is run through the course. At the same time, the course project is divided into various unit projects, requiring students to complete the planning, implementation, publication and achievement submission of each item in the form of a group. The content should be preached to the students at the first lecture of the course so that students can understand them in advance and plan the specific content of each part as they learn. In order to effectively guide students to carry out the project, need to provide project guidance to students as a reference. Due to space limitations, only a brief introduction in this article.

The current Japanese writing courses are mostly confined to the classroom, mainly teacher $\rightarrow$ teacher write $\rightarrow$ teacher change, the form of a single. With the popularization of the Internet, students show great interest in e-learning materials. At the same time, writing courses tend to be limited in time and can hardly be adequately trained only by the time of the class. Therefore, multimedia courses and courses can be flexibly used Web site for students to prepare for the project under the class, preview review and so on. However, the amount of basic materials required for business Japanese writing courses to be provided to students is large. If the curriculum resource sharing platform can be constructed, the exchange and sharing of curriculum resources between schools can be realized, which saves manpower and material resources to a great extent and improves the curriculum construction effectiveness. 


\section{Conclusion}

Japanese teaching reform has just started, and while we are actively exploring and experimenting, we certainly face various difficulties and challenges. In fact, in practical teaching, engineering, management and other disciplines have already started a variety of useful exploration and research, many of them effective teaching methods and concepts, can be an appropriate reference in Japanese teaching. Therefore, it is recommended that Japanese educators be able to break the boundaries between disciplines and learn from others, providing more ideas and experiences for Japanese education and Japanese education reform.

\section{References}

[1] Liu Yafen. Study on the Construction of Japanese Writing Course Cooperated by School and Enterprise [J]. Talent. 2015 (21)

[2] Cui Linjie. Japanese Writing Course Formative Evaluation of the Construction and Research [J]. China Science Education Innovation. 2014 (11)

[3] JIANG Wei. Application of CDIO Education and Teaching Concept in Japanese Writing Course [J]. Journal of Jilin Institute of Education (Early Edition). 2014 (03)

[4] LI Xiang. Research and Practice of Teaching Methods of Japanese Writing Course Practice [J]. Journal of Literature (Theory Edition). 2012 (11)

[5] Xu Lingzhi. Research on Japanese teaching mode with multimedia network technology [J]. Heilongjiang Science and Technology Information. 2011 (22) 